\title{
Comparing the special education system in the Kingdom of Saudi Arabia and the United Kingdom
}

\author{
Khalid Mohammed Almahrag \\ Special Education, King Saud University, 3749 Riyadh 12372 - 7959, Kingdom of Saudi Arabia \\ *E-mail of the corresponding author: almahrej@yahoo.com
}

\begin{abstract}
This paper is a general literary review. To compare the education system for people with special needs in the Kingdom of Saudi Arabia and the United Kingdom since the two systems were established to identify the best methods of providing services in the two systems and the extent to which the cultural and social dimension affects the provision of those services. The research found through this review that there is a convergence in some methods of providing services and a difference in some of them due to these two countries' different cultural and social nature.
\end{abstract}

Keywords: Special Education Needs in Saudi Arabia, Special Education Needs of United Kingdom

DOI: $10.7176 / \mathrm{JEP} / 12-18-09$

Publication date:June $30^{\text {th }} 2021$

\section{Introduction}

Over the last few years, the number of families relocating to the U.K. with children who have learning difficulties has dramatically increased. However, it has come as something of a shock to large numbers that, unlike their home environment, the children will not necessarily be mainstream - indeed, that usually is far from the case. Likewise, parents have decided that they will not inform the schools they are trying to enter that their child might have special needs until they are in the meetings with respective heads, hoping that it will not matter. Only then to told that the school cannot or indeed will not cope with the level of need required. One family, for example, placed on their application that their son needed Speech Therapy, but it was not a significant need. The file on the student arrived at one of the International Schools and was an inch thick - the school felt it could not cater for the child, and the parents were devastated. Eventually, the young man concerned was placed in a school, which could cater for the need and prepare him for the International School later - if only they had indicated that situation upfront, the situation would have been so different and the distress to parents and child mineralized.

Compare the special education needs of Saudi Arabia and the United Kingdom will be better for us to analyze them separately. It will give more thoughtful insight into the picture.

\section{Special Education Needs in Saudi Arabia}

Education has been a primary goal of a government in Najd since the late eighteenth century, when the Wahhabi movement encouraged Islamic education for all Muslim believers. Because the purpose of Islamic education was to ensure that the believer would (Hamdan,2005), say understand Gods' laws and live his or her life by them, classes for reading and memorizing the Quran and selections from the hadith sponsored in towns and villages throughout the peninsula. At the most elementary level, education took place in the Qutab, a class of Quran recitation for children usually attached to a mosque, or as a private tutorial held in the home under a male or female professional Quran reader, which was usually the case for girls. In the late nineteenth century, nonreligious subjects were also taught under Ottoman rule in the Hijaz and Al Ahsa Province. Where kuttab schools specializing in Quran memorization sometimes included arithmetic, foreign language, and Arabic reading the curriculum. Because the purpose of essential religious learning was to know the contents of holy scripture, the ability to read Arabic text was not a priority, and illiteracy remained widespread in the peninsula. In 1970, compared to all Middle East and North Africa countries, the literacy rate of 15 percent for men and 2 percent for women in Saudi Arabia was lower only in Yemen and Afghanistan. the steep rise in literacy rates--by 1990, the literacy rate for men had risen to 73 percent and that for women to 48 percent--must be seen as an achievement. (Muhammad, 1997) 
Exceptional students who wished to pursue their studies at the elementary level could attend an informal network of introductory lectures (halaqah) offering instruction in Islamic jurisprudence, Arabic language, Quranic commentaries (tafsir), hadith, literature, rhetoric, and sometimes arithmetic and history. In Saudi Arabia, higher studies in the primary religious ship were formalized in 1945 with the At Taif School of Theology (Dar alTawhid). In the early 1990 s, there were two school-level institutions for religious studies, the Islamic School of Medina and the Imam Muhammad ibn Saud Islamic School in Riyadh.

By 1989 Saudi Arabia had a unique education system with more than 14,000 education institutions, including seven universities and eleven teacher-training schools and schools for vocational and technical training, special needs, and adult literacy. General, special education consisted of kindergarten, six years of primary school, and three years of intermediate and elementary (high) school. Administratively, two organizations oversaw most special education institutions in the kingdom. The Ministry of Special education supervised the special education of boys, special education programs for the disabled, adult special education, and junior schools for girls". Special education is administered by the Directorate General Girls' Special education, an organization staffed by ulama, working closely with the Ministry of Special education. The directorate general oversaw the general, special education of girls, kindergartens, and nurseries for girls, women's literacy programs, and schools of special education and junior schools. The Ministry of Higher Special education was the authority overseeing the kingdom's schools and universities.

Public special education, at the elementary-school level, has never been fully separated from its Islamic roots. At the elementary-school level, an average of nine periods a week was devoted to religious subjects and eight per week at the intermediate-school level. This concentration on religious subjects was substantial when compared with the time devoted to other subjects: nine periods for Arabic language and twelve for geography, history, mathematics, science, art, and special physical education combined at the elementary level; six for Arabic language and nineteen for all other subjects at the intermediate level. At the elementary level, the required periods of the religious study reduced, although an option remained for a concentration in religious studies. (Afroz, 1988)

The policy also recognizes "women's right to obtain suitable special education on equal footing with men in light of Islamic law." One exception was that only boys took special physical education at all levels of pre-school special education, and only girls took home economics.

Inequalities of opportunity existed in higher special education that stemmed from the religious and social imperative of gender segregation. Gender segregation was required at all levels of special public education and demanded in public areas and businesses by religiously conservative groups and social conventions. The social perception was that men would put the knowledge and skills acquired to productive use; fewer resources were dedicated to women's higher special education than men. This constraint was a source of concern to economic planners and policymakers because training and hiring women would help solve the difficulties of indigenizing the workforce and help satisfy the rising expectations of the thousands of women graduating from elementary schools, schools, and universities.

The concern is compounded by the fact that women have excelled academically over males in elementary schools. The number of female graduates has outstripped the number of males, even though the number of girls entering school was considerably lower than that of boys. The number of female elementary level graduates has increased more than tenfold, from 1,674 in 1975 to 18,211 in 1988. Under conditions existing in the early 1990s, the problem can only become more acute because the Fifth Development Plan projected 45,000 female elementary school graduates in 1995 and only 38,000 male graduates.

This increase in women graduates has not been met by a commensurate increase in higher exceptional education opportunities. Despite the substantial expansion of the school and school programs for women, they remained insufficient to serve the graduates who sought admission. The Fifth Development Plan cited higher special education for women as a significant issue to address. Saudi press reports in 1992 indicated that there was a discussion of creating women's schools. (ARAB CENTRE for Development and Future Research, 1988)

A significant objective for special education in the Fourth Development Plan and the Fifth Development Plan has been to develop general, special education to deal with technological changes and rapid developments in social and economic fields, to replace a portion of Saud Arabians' massive foreign labor force (79 percent of the total in 1989) with indigenous workers. In the late 1980s, a high rate of unique student dropouts and elementary school failures precluded realizing these goals. (In 1990, the ratios of the number of exceptional students at the primary, intermediate, and elementary levels to the total number of exceptional students stood at 69.6, 20.5, and 9.9 percent, respectively.) One means of addressing the dropout problem was a program initiated in 1985 by Calle" 
"developed special elementary education," designed to prepare special students for school study as well as for practical participation in the workforce. In this program, the student could select two-thirds of his or her study plan from courses with practical applications or genuine appeal to the special student's interests and abilities. After completing a required general program consisting of courses in religion, mathematics, science, social studies, English, Arabic, and computers, special students elected a course of study in three concentrations: Islamic studies and literature, administrative science, and humanities the natural sciences. (Adil, 1987)

Another goal in both the Fourth Development Plan and the Fifth Development Plan has been to indigenize the elementary teacher corps. This gain resulted from the increase during the 1970s of institutes for training teachers and the more significant material incentives for careers in special education, stipulated in a royal decree of 1982. Nonetheless, training schools for teachers had trouble attracting candidates, especially males; male enrollment declined slightly, whereas female enrollment nearly tripled. In 1984, about 12,000 women enrolled in the seven female special education schools in Riyadh, Jeddah, Mecca, Medina, Buraydah, Abha, and Tabuk. This move would allow graduates the opportunity to complete a school special education for a bachelor's degree and thus draw more potential candidates to the teaching profession.

Government funding for higher special education has been particularly munificent. Between 1983 and 1989, the number of school students increased from approximately 58,000 to about 113,000, a 95 percent increase. Equally dramatic was the increase in the number of special students at the school level: from 20,300 to 47,000 during the same period, or a 132 percent increase. The new campus of King Saud School in Riyadh, built in the early 1980s, was designed to accommodate 25,000 special male students; the original school buildings in central Riyadh converted into a campus for the women's branch School. King Saud School included administrative sciences, agriculture, arts, dentistry, special education, engineering, medical sciences, medicine, pharmacy, and science. In 1984 there were 479 special graduate students, including 151 women.

The School of Petroleum and Minerals (King Fahd School) in Dhahran, founded in 1963, offered undergraduate and graduate degree programs in engineering and science, with most programs of study offered in English. Also in Dhahran was King Faisal School, founded in 1976, with schools of agricultural sciences and foods, architecture, special education, medicine, and veterinary medicine. In 1984 some 40 percent of its 2,600 special students were women.

Founded in 1968, the school in 1990 had about 15,000 undergraduate special students, of whom about one-third were women. It consisted of nine schools, including arts and sciences, environmental studies, marine sciences, medicine, and meteorology. The school's expansion plans, funded by an investment of US\$2 billion, called for the addition of schools of special education, environmental design, pharmacy, and planning and technology. The completed expansion should accommodate 25,500 special students, with a medical complex to include a hospital, a health services center, and a medical research facility. (Abu Harb, 1992)

The expansion of the school system in Saudi Arabia has enabled the kingdom to limit financial support for study abroad. Since the mid-to the late 1980s, the number of Saudi special students going abroad to study has dropped sharply. In the 1991-92 school year, only 5,000 special students were reported studying abroad; there were slightly more than 4,000 the previous year, with half of those studying in the United States. These figures contrasted with the approximately 10,000 special students studying abroad in 1984. As in the past, special students going abroad to study received substantial financial assistance. (Abu Harb, 1992) Special students selected to receive government funding to study abroad in 1992 received tuition, lodging, board, and transportation allowances. Those intending to study science or technology received an additional stipend as an additional buffer against such potential problems, an orientation program in Islamic and foreign cultures offered at Imam Muhammad ibn Saud Islamic School for special students to go abroad.

The expansion of formal religious special education programs in a technologically modernizing society has created economic dislocations and social polarization between those equipped primarily with special religious education and those prepared to work in the modern economic sector. Consequently, the growing number of graduates in religious studies--in 1985, 2,733 special students in the Islamic School of Medina and more than 8,000 in Muhammad ibn Saud School in Riyadh--was a potential source of disaffection state and its modernizing agenda.

\section{Special Education Needs of United Kingdom}

At a recent national educational research conference, a contributor to a symposium on aspects of special educational needs (SEN) provision chose to open with a striking allegory (Slee, 1996). Thus, he narrated how, 
following the closure of the bar after the conference dinner? he had chanced upon a colleague on his hands and knees in a pool of light shed by lamplight and scrabbling the ground in front with his fingers ' What is the matter, Dav'?' he inquired 'I have lost wristwatch, came the reply' 'Where did you lose it" "Over there, replied Dave pointing to the shadows to his left .'Why, then, are you searching her" ?"Because there is some light here, waves' response. The contributor intended to shift 'our research gaze away from the more politically correct inclusive education research and provision to reconsider what is happening in special school provision (Slee, 1996). the intention may well appear valid; what if that too is off the mark regarding an analysis of SEN? Is SEN analysis in the light or the shade?

The Education Act 1944 had required each local education authority (LEA) to ensure that all children were educated by their 'age, ability, and aptitude. Regulations attendant upon the Act set out eleven categories o' 'disabled pupils' (Ministry of Education, 1945). Nine of the eleven categories identified aspects of pupils' physical conditions; the tenth was 'educationally subnormal and the eleventh 'maladjusted. The eleven categories of handicaps were the basis for the organization of a system of separate special schools. These handicapping categories may also be regarded as the apotheosis of the medical model of an educational disability, whose prevalence can trace from the origins of the state's provisions for elementary school education in 1870 (Tomlinson, 1982, pp. 26-57). The essence of the medical model is the proposition that the pupil displays symptoms of deficiency that an expert can diagnose. However, that is not to argue that experts worked without sensitivity within this model (Corbett, 1990, pp. 185-198).

Some 30 years later, the Warnock Committee (Department of Education and Science, 1978) sought to abolish the eleven handicapping categories arguing as follows: firstly' 'their use pins a single label on each handicap and each special school (p. 42), but this may produce intractable problems of classification in those cases of multiple handicaps; secondly' 'categorization promotes confusion between child's disability and the form of special education he (sic) needs (p. 42) by emphasizing the child's condition rather than educational need; thirdly, the process of labeling may demean children so that thos' 'diagnosed as ESN(M) or maladjusted can be stigmatized unnecessarily for the whole of their school careers and beyond (p. 42); and fourthly, their use as the basis for organizing special provision diverts resources away from those children who may not fit into the categories. Warnock regarded this whole process as emphasizing the negative and deficient dimension of the child. In its place should be a more positive approach based upon 'the concept of S'N' (Department of Education and Science, p. 37). Here the focus should be firmly upon the educational rather than the medical.

Although some recommendations were not accepted (cf Wedell, 1993, p. 2), the Education Act 1981 espoused the Warnock philosophy and so much so that it claimed that 'The Act is referred to by members of the Government as the" "Warnock legislation" " (National Union of Teachers, 1982, p. 6). Section 1 of the Act presented a definition of SEN in terms of the interrelationship between ideas 'learning difficulty and 'special educational provision.' Thus' '... a child has SEN if he has a learning difficulty which calls for special educational provision to made for him (sic) ... (and) a child has a learning difficulty if:

(a) he has significantly more incredible difficulty in learning than most children of his age.

(b) he has a disability that either prevents or hinders him from making use of educational facilities of a kind generally provided in schools within the area of the local authority concerned for children of his age; or

(c) he is under the age of five years and is, or would be if the special educational provision not made for him, likely to fall within paragraph (a) or (b) when over that age (Act, E,1981)

'Special educational provision means. The educational provision is additional to, or otherwise different from, the educational provision made generally for children of his age in schools maintained by the LEA concerned. Also, it noted that a different form of language use between home and the school does not alone constitute having a learning difficulty.

The first part of this definition is a major source of difficulty because 'learning difficulty an' 'special educational provision is defined contingently in relationship to each other. There are different forms that definitions may take. A major distinction lies in an explicit definition that gives the word or phrase the same as the defined word. For example, 'triangle means' 'three-sided plane figure where terms outside itself explicitly define the first term. A definition is contextual or circular

where the word to be defined is used in giving the definition. Such definitions are useless for example, the following three definitions taken together are circular" "mendacious"y" mean" "lack of veracity"y"' "veracity"y" mean" "absence of prevarication"n"; an" "prevaricate"n" mean" "mendacious"y". (Salmon, 1963, p. 92)

From this fact emerge' 'the circularity of the definition which, in seeking to clarify the concept of SEN, 
introduces two other concepts" "special educational provision"n" an" "learning difficulty"y," without offering precise meanings for any of them (Goacher et al., 1988, p. 10). This difficulty further compounded without a precise measure fo' 'significantly greater for learning difficulty or an index o' 'facilities ... generally available in LEAs.

The remaining problem is that of the continuing persistence of the inadequate and contingent definition of SEN. It is explicable within the overall context of normalization, where the normative judgment prevails. The idea $o^{\prime}$ 'learning difficulties lacks parameters in both the dimension of learning and that of difficulties. The absence of precise lines of demarcation supports the play of normative judgment. Hence, pseudo-science and dividing practices gave relatively free rein. The arena where aspects of SEN attain precise definition lies beyond education in law courts (cf. Gross, 1996, pp. 3-11). A methodological principle of the Frankfurt School and shared by the judicial bench was cui bono? In whose interests is it that the definition of SEN should persist in inadequacy?

Finally, it should not be assumed that the process of normalization runs a smooth course. Precisely because its scientific basis may be in contestation and because its judgments are normative, there may be struggles between disagreeing factions. In this context, the discourse--the set of ideas advocated for practical implementation-concerning the exclusion of pupils from the mainstream generated by the NASUWT is informative. The Union frequently presents a vociferous objection to disruptive pupils in the classroom and has even suggested that it would be better if such pupils were out on the streets committing their acts of vandalism since the acts of disruptive pupils disrupt the learning of other pupils. The whole essence of this discourse diverts attention from contextual and pedagogical considerations to lay the blame upon the personal characteristics and symptoms of the child. Thus, the excluded pupil is pathologies. It also constitutes the rediscovery of the medical model of pupil deficiency to explain an educational phenomenon.

\section{Conclusion}

According to a report from the Saudi Arabia University, special education teachers in Saudi Arabia lack the necessary classroom skills. Under a project financed by the UAEU research affairs section, a program to help teachers acquire the right skills developed with a behavioral approach. People with special needs are found in the general population of Saudi Arabia who is of Arabic descent. It is difficult to estimate the percentages in each of the usual special need's categories (e.g., Autism or Cerebral Palsy) since no central data collection agency exists. Evidence would suggest that the percentage of people with disabilities in Saudi Arabia is like the worldwide average, i.e., 8-10 percent of the population.

No federal legislation requires accessibility for people with special needs (Bradshaw, Tennant\& Lydiatt,2004). The government sponsors several centers to provide facilities and services. Services include funds, special education, and transportation to sending a team to the Special Olympics. Concerning students with special needs, the Ministry of Education and Youth also involved in two separate departments: the private school system and the public domain. At present, a specific categorical system for identifying and supporting students with special needs does not exist formally.

The public system has staff at the upper Ministry level and in each of the regional divisions across the country who support the unique education system. Educational psychologists and speech-language pathologists provide school-based assessments and consultative support to schools. It is usually accomplished through a referral system generated at the school level. A screening system determines selected clients for special supports. Within most Ministry schools, counselors provide support for social-emotional needs. They also act as one of the frontline resources for identifying and referring students with special needs. The Ministry of Labor and Social Affairs is drafting a new law that will require private sector companies with more than 100 employees to reserve three percent of jobs for people with special needs.

In Saudi Arabia, job opportunities are minimal for people with disabilities. Among the 1422 people with disabilities in Abu Dhabi (the capital city), only 20 persons were employed.

\section{References}

ABD ALLAH, Layla `Abd Allah Muhammad (1997) Ahkam al-akhras fi al-fiqh al-Islami. (MA thesis, Jamiat alAzhar, 1996) Cairo: Maktabat al-Zahra.

ABD UL-ILAH Bin 'Uthman ash-Shay (1997) [compilerAl-Lu'lu'u' uth-ThamiFatwa' 1-Mu'awwaqinin, Riyadh: 
Daas-Sumay'i i.

ABD UR-RAHMAN `Abd ul-Khaliq [1995] Al-Mushawwiq fi Ahkaal-Mu'awwaqaq [a Fascinating Treatise Concerning the Rules and Regulations for the Disabled], al-Hikmah 7: [p. 145], [London: Jamada atThaniyah.]

ABU HARB Q (1992) Mu'asasat Al-Mu'aqeen Fi Al-Diffah Al-Gharbiah: Waqia'ha, Khadamatuha, Hajatuha. [Institutions of disabled people in the West Bank: conditions, services, and needs.] East Jerusalem: Arab Studies Society.

ABU HOMMOS N (1986) Alnathra Hawl Almuakeen Fi al Diffa AlgharbiWakita'a' Ghaza. [Attitudes towards disabled people in the West Bank and Gaza Strip.] Nablus: An-Najah Ntl Univ.

AFROOZ GA (1988) Farsi: [Introduction to Psychology and Education of Exceptional Children. Tehran: Tehran UP.]

ARAB CENTRE for Development and Future Research (1988) Arabic: [The social framework for the disabled in the Arab society.]

ASHWAL, Adil Ahmad Izz al-Din [ed] (1987) Mawsu`at al-tarbiyah al-khassah: Injilisi-Arabi. Cairo: Maktabat al-Anjlu al-Misriyah. 1078 pp.

AUDIT COMMISSION HEMAJESTY'S INSPECTORATE (1992) getting in on the Act: provision for pupils with SEN: the national picture (London, HMSO)

BENNETTO, J. (1997) Lock them up by all means but not in my backwater, The Independent, 6 February, p. 1.

BURREL, I. (1997Jails" watchdog angry at Home Office delays, The Independent, 31 January, p. 6.

CARTER, J. (1997) Post-Fordism and the theorization of educational change what is in a name? British Journal of Sociology of Education, 18(1), pp. 45-61.

CENTRAL STATISTICAL OFFICE (1996) Social Trends 26 (London, HMSO).

CORBETT, J. (1990) Watching and listening: pediatrician's career, 1944-1986, Disability, Handicap and Society, 5(2), pp. 185-198.

DEAN, C. (1996Shephard's's U-turn on tests, Times Educational Supplement, 9, February, p. 2.

DEAN, M. (1994) Critical and Effective HistoriesFoucault's methods and historical sociology (London, Routledge).

DEPARTMENT OF EDUCATION AND SCIENCE (1978) Special Educational Needs (London, HMSO).

DEPARTMENT FOR EDUCATION (1993) National Exclusions Reporting System (DFE).

DEPARTMENT FOR EDUCATION (1994) The Code of Practice on the Identification and Assessment of SEN (London, HMSO).

DEPARTMENT FOR EDUCATION (1995) National Survey oLEAs's Policies and Procedures for the Identification, and Provision for, Children who are out of school because of Exclusion or Otherwise (DFE).

DONZELOT, J. (1979) The Policing of Families (London, Hutchinson).

FEUER, L.S. (1971) Marx and Engels: essential writings on politics and philosophy (London, Collins).

FOUCAULT, M. (1977) Discipline and Punish: the birth of the prison (London, Allen Lane).

FOUCAULT, M. (1982) The subject and power, in: H.L. DREYFUS \& P. RABINOW, Michel Foucault: beyond structuralism and hermeneutics (Brighton, Harvester).

GIBSON, R. (1986) Critical Theory and Education (London, Hodder \& Stoughton).

GIPPS, C., GROSS, H. \& GOLDSTEIN, H. (1987Warnock's Eighteen percent (London, Falmer).

GOACHER, B., EVANS, J., WELTON, K. \& WEDELL, K. (1988) Policy and Provision for SEN: implementing the 1981 Education Act (London, Cassell).

GROSS, J. (1996) The weight of evidence: parental advocacy and resource allocation to children with statements of SEN, Support for Learning, 11(1), pp. 3-8.

GUTTING, G. (Ed.) (1994) The Cambridge Companion to Foucault (Cambridge, Cambridge University Press).

HAWARD, R. (1997) The New Education Bill, The Times Educational Supplement, S2, 24 January, p. 24. 
HOME OFFICE INFORMATION AND PUBLICATIONS GROUP (1997) Life Licensees: reconvictions and recalls by the end of 1995 (Croydon, HOIPG).

MERQUIOR, J.G. (1991) Foucault (London, Fontana Press).

MINISTRY OF EDUCATION (1945) Statutory Rules and Orders No. 1076, The Handicapped Pupils and Health Service Regulations.

MORRIS, R., REID, E. \& FOWLER, J. (1993) Education Act 93: A Critical Guide (London, Association of Metropolitan Authorities)

NATIONAL UNION OF TEACHERS (1982) The Education Act 1981: A Union Guide (London, NUT).

NORBURY, B. (1993) Education Bill: special educational needs (London, DFE).

NORWICH, B. (1990) Reappraising Special Needs Education (London, Cassell).

NUTTALL, D.L. (1989) The implications of National Curriculum Assessments, Educational Psychology, 8(4), pp. 229-236.

OFFICE FOR STANDARDS IN EDUCATION (1997) The Annual Report of HeMajesty's's Chief Inspector of Schools: standards and quality, in education 1995/96 (London, The Stationery

Office). PARSONS, C. (1996) Permanent exclusions from schools in England in 1990s: trends, causes, and responses, Children and Society, 10, pp. 177-186.

PULLMAN, P. (1997) Understand a little more, The Independent S2, 1 February, p. 2.

RABINOW, P. (1991) The Foucault Reader (London, Penguin Books).

ROSE, N. (1985) The Psychological Complex: psychology, politics, and society in England, 1869-1939 (London, Routledge).

ROSE, N. (1989) Governing the Soul: the shaping of the private self (London, Routledge).

SALMON, W.C. (1963) Logic (Englewood Cliff, NJ, Prentice-Hall).

SLEE, R. (1996) Reversing the Analytical Gaze? Movements in Special Educational Research and Provision, paper presented at the British Educational Research Association Annual Conference.

SMART, B. (1988) Michel Foucault (London, Routledge).

TASK GROUP ON ASSESSMENT AND TESTING (1987) National Curriculum: A Report (London, DES).

TOMLINSON, S. (1982) A Sociology of Special Education (London, Routledge \& Kegan Paul).

TOMLINSON, S. (1988) Why JohnnCan't't Read: critical theory and special education, European Journal of Special Needs Education, 3(1), pp. 45-58.

WEDELL, K. (1993) Special needs education: the next 25 years, National Commission on Education, Briefing No. 14 (London, Paul Hamlyn Foundation).

Hamdan, A. (2005). Women and education in Saudi Arabia: Challenges and achievements. International Education Journal, 6(1), 42-64

Act, E. (1981). Chapter 60. URL: http://www. legislation. gov. uk/ukpga/1981/60/enacted [in English].

Bradshaw, K., Tennant, L., \& Lydiatt, S. (2004). Special education in the United Arab Emirates: anxieties, attitudes, and aspirations. International journal of special education, 19(1), 49-55. 